\title{
Markers of inflammation are associated with clinical outcomes in patients with metastatic renal cell carcinoma treated with nivolumab
}

\author{
Mario Sznol ${ }^{1 *}$, Mayer Fishman ${ }^{2}$, Bernard Escudier ${ }^{3}$, David F McDermott ${ }^{4}$, Harriet Kluger ${ }^{5}$, Walter M Stadler ${ }^{6}$, \\ Jose Perez-Gracia ${ }^{7}$, Douglas G McNeel ${ }^{8}$, Brendan D Curti ${ }^{9}$, Michael R Harrison ${ }^{10}$, Elizabeth R Plimack ${ }^{11}$, \\ Leonard Appleman ${ }^{12}$, Lawrence Fong ${ }^{13}$, Charles G Drake ${ }^{14}$, Tina C Young ${ }^{15}$, Scott D Chasalow ${ }^{15}$, \\ Petra Ross-MacDonald ${ }^{15}$, Jason S Simon ${ }^{15}$, Dana Walker ${ }^{15}$, Toni K Choueiri ${ }^{16}$ \\ From 30th Annual Meeting and Associated Programs of the Society for Immunotherapy of Cancer (SITC \\ 2015) \\ National Harbor, MD, USA. 4-8 November 2015
}

\section{Background}

In previously treated patients with metastatic renal cell carcinoma (mRCC), the programmed death-1 (PD-1) inhibitor antibody nivolumab demonstrated objective response rates of $20 \%-22 \%$ and median overall survival (OS) of 18.2- 25.5 months[1]. An exploratory biomarker analysis of baseline and on-therapy changes was conducted to investigate the relationship between the clinical and immunomodulatory activity of nivolumab.

\section{Methods}

Patients with 1-3 prior therapies for $\mathrm{mRCC}$ received nivolumab $0.3,2$, or $10 \mathrm{mg} / \mathrm{kg}$ IV every 3 weeks (Q3W); treatment-naïve patients received $10 \mathrm{mg} / \mathrm{kg}$ IV Q3W. Biopsies and peripheral blood mononuclear cells were obtained at baseline and cycle 2 day 8 . Tumor burden reduction was defined as a $\geq 20 \%$ decrease. Gene expression data were obtained on Affymetrix U219. OS parameters were estimated by the Kaplan-Meier method or by Cox proportional hazards regression. PD-1 ligand 1 (PD-L1) expression was measured by tumor membrane immunohistochemical staining (28-8 antibody; Dako) in baseline biopsies. Serumsoluble factors were quantified using a Luminex multiplex panel (Myriad Rules-Based Medicine). T cell receptor sequencing was conducted with the immunoSEQ assay (Adaptive Biotechnologies).

Yale Comprehensive Cancer Center, New Haven, CT, USA Full list of author information is available at the end of the article

\section{Results}

91 patients were treated. 59 baseline and 55 on-therapy biopsies were evaluable for gene expression, with 42 matched samples. Patients with tumor burden reduction had differential expression ( $>1.3$-fold, $P<0.01$, q-value $<$ $0.16)$ of 311 genes at baseline $(n=13)$ and 779 genes ontherapy $(\mathrm{n}=11)$ compared with patients without tumor burden reduction, including higher expression of transcripts associated with cell-mediated immunity. CTLA-4, TIGIT, and PD-L2 transcripts were present at higher levels on-therapy in patients with tumor burden reduction. Table 1 summarizes OS and OS by PD-L1 expression. $18 / 56$ biopsies (32\%) had $\geq 5 \%$ PD-L1 expression. Among serum-soluble factors, recognized prognostic markers (VEGF, ICAM1, VCAM1, TIMP1) were associated with OS. Based on $\mathrm{T}$ cell sequencing, increased tumor $\mathrm{T}$ cell counts and decreased blood $\mathrm{T}$ cell clonality at baseline were associated with longer OS.

\section{Conclusions}

Immune markers at baseline and on-therapy suggest preexisting adaptive immunity is associated with nivolumabinduced tumor regression. Upregulation of immune checkpoint molecules provides rationale for study of nivolumab and ipilimumab combination in mRCC. A minimal difference in OS by PD-L1 expression was observed for up to 2 years.

\section{Trial registration}

ClinicalTrials.gov identifier NCT01358721. 
Table 1

\begin{tabular}{|c|c|c|c|}
\hline & \multirow[t]{2}{*}{ Median OS, mo (95\% Cl) } & \multicolumn{2}{|c|}{ OS rate, \% (95\% Cl) } \\
\hline & & $1-\mathrm{yr}$ & $2-y r$ \\
\hline \multicolumn{4}{|l|}{ Treatment group } \\
\hline $0.3 \mathrm{mg} / \mathrm{kg}(\mathrm{n}=22)$ & 16.4 (10.1-NR) & $71(47-86)$ & $44(22-64)$ \\
\hline $2.0 \mathrm{mg} / \mathrm{kg}(\mathrm{n}=22)$ & NR & $72(48-86)$ & $61(36-78)$ \\
\hline $10 \mathrm{mg} / \mathrm{kg}(\mathrm{n}=23)$ & $25.2(12.0-\mathrm{NR})$ & $74(48-88)$ & $51(27-71)$ \\
\hline 10 mg/kg (naïve) (n=24) & NR & $81(57-92)$ & $76(51-89)$ \\
\hline \multicolumn{4}{|l|}{ PD-L1 expression } \\
\hline$\geq 5 \%(n=18)$ & NR & $71(44-87)$ & $64(37-82)$ \\
\hline$<5 \%$ mg/kg $(n=38)$ & $23.4(13.1-33.3)$ & $71(52-83)$ & $48(30-64)$ \\
\hline
\end{tabular}

$\mathrm{NR}=$ not reached

\section{Acknowledgements}

Dako, for collaborative development of the automated PD-L1 immunohistochemistry assay. Adaptive Biotechnologies, for T cell repertoire analysis.

\section{Authors' details}

${ }^{1}$ Yale Comprehensive Cancer Center, New Haven, CT, USA. ${ }^{2}$ Department of Medical Oncology, H. Lee Moffitt Cancer Center and Research Institute,

Tampa, FL, USA. ${ }^{3}$ Department of Medical Oncology, Institut Gustave Roussy, Villejuif, France. ${ }^{4}$ The Cytokine Working Group; Division of Hematology/ Oncology, Beth Israel Deaconess Medical Center, Boston, MA, USA.

${ }^{5}$ Department of Medical Oncology, Yale Cancer Center, New Haven, CT, USA.

${ }^{6}$ University of Chicago Medicine, Chicago, IL, USA. ${ }^{7}$ Department of Oncology, University Clinic of Navarra, Pamplona, Spain. ${ }^{8}$ Department of Medicine, University of Wisconsin-Madison, Madison, WI, USA. ${ }^{9}$ Providence Cancer Center, Providence Portland Medical Center, Portland, OR, USA.

${ }^{10}$ Department of Surgery, Duke University Medical Center, Durham, NC, USA.

${ }^{11}$ Department of Medical Oncology, Fox Chase Cancer Center, Philadelphia, PA, USA. ${ }^{12}$ Department of Medicine, University of Pittsburgh Medical Center Cancer Pavilion, Pittsburgh, PA, USA. ${ }^{13}$ Department of Medicine, University of California San Francisco Helen Diller Family Comprehensive Cancer Center, San Francisco, CA, USA. ${ }^{14}$ Department of Oncology, Sidney Kimmel Comprehensive Cancer Center at Johns Hopkins University, Baltimore, MD, USA. ${ }^{15}$ Bristol-Myers Squibb, Princeton, NJ, USA. ${ }^{16}$ Department of Medicine, Dana-Farber Cancer Institute, Boston, MA, USA.

Published: 4 November 2015

\section{Reference}

1. Motzer RM, et al: Nivolumab for metastatic renal cell carcinoma: results of a randomized phase II trial. J Clin Oncol 2015, 33:1430-1437.

\section{doi:10.1186/2051-1426-3-S2-P197}

Cite this article as: Sznol et al:: Markers of inflammation are associated with clinical outcomes in patients with metastatic renal cell carcinoma treated with nivolumab. Journal for ImmunoTherapy of Cancer 20153 (Suppl 2):P197.

\section{Submit your next manuscript to BioMed Central and take full advantage of:}

- Convenient online submission

- Thorough peer review

- No space constraints or color figure charges

- Immediate publication on acceptance

- Inclusion in PubMed, CAS, Scopus and Google Scholar

- Research which is freely available for redistribution

Submit your manuscript at www.biomedcentral.com/submit
Ciomed Central 